SCHACKT Jon, A people of stories in the forest of myth: the Yukuna of Miritiparaná

Novus Press, Oslo, 2013

\title{
Chloé Nahum-Claudel
}

\section{(2) OpenEdition}

\section{Journals}

Electronic version

URL: https://journals.openedition.org/jsa/14017

DOI: 10.4000/jsa. 14017

ISSN: 1957-7842

\section{Publisher}

Société des américanistes

\section{Printed version}

Date of publication: 31 December 2014

Number of pages: 248-252

ISSN: 0037-9174

\section{Electronic reference}

Chloé Nahum-Claudel, "sснаскт Jon, A people of stories in the forest of myth: the Yukuna of Miritiparaná", Journal de la Société des américanistes [Online], 100-2 | 2014, Online since 01 July 2015, connection on 04 September 2022. URL: http://journals.openedition.org/jsa/14017 ; DOI: https://doi.org/10.4000/jsa. 14017

This text was automatically generated on 4 September 2022.

All rights reserved 


\section{SCHACKT Jon, A people of stories in the forest of myth: the Yukuna of Miritiparaná}

Novus Press, Oslo, 2013

Chloé Nahum-Claudel

\section{REFERENCES}

SCHACKT Jon, A people of stories in the forest of myth: the Yukuna of Miritiparaná, Novus Press, Oslo, 2013, 271 p., bibl., photos, illustrations, cartes

1 Yukuna means « stories ». Yukuna consider themselves caretakers of an oral tradition "left behind by some mythical Yukuna, more "real" than them » (p. 28). Everything in the present takes its significance and potency from what is known about its origin and past. But ancestral authority is both absolute and flexible here (ibid.). Since Yukuna have no priestly specialists and since every Yukuna man is something of a shaman, claims to seniority are there to be made, through narrations of nacimiento, origin stories. These invariably begin with a story about the apical ancestor of the patri-sib and his maloca, and work through elaborate genealogies of 10 or 12 generations (p. 184), towards the present. In this way Yukuna men anchor their identities in interpretations of genealogical succession. These are open to contestation, and narrators concentrate on different branches of the diverging genealogical tree to justify their claims to seniority. Stories do not make Yukuna authority by fiat of patrilineal succession from the right ancestor; rather Yukuna men have to elevate themselves by confecting long and elaborate narratives, which weave historical legend into epic mythic sagas before coming back to the present day. It also helps to host dance parties and to have a large maloca (p.21). Leadership contests are easily smoothed over with the oft-spoken affirmation that all Yukuna are " one maloca » because all are juniors in respect to the ancestors, all trace their origin to a common maloca and origin place. 
2 The book's ethnographic present is 1984-1985, when the author conducted fieldwork with his anthropologist partner, Carla Matallana Laverde, in maloca communities belonging to the five patrisibs; these, either by heritage, affinal adoption, or borrowing, today speak Yukuna and narrate Yukuna history as their own. It is fair to say that the predominant perspective is that of the Kamejeya patri-sib, whose members are considered the " only true Yukuna ». Chapters one to three are introductory. The first chapter presents the book's thematic heart, which is the imbrications of legend, myth and history; and the relations between ancestrality, hierarchy and the politicisation of knowledge. Schackt asks why some peoples rely on myth so much, whereas others (he gives the example of the Pirahã) do so little. The author follows Bloch (1977) in his suggestion that this has to do with the hierarchical cast of Yukuna society, which relies on men in the present day appropriating ancestral authority for themselves. He also critically discusses the old issue of hot and cold societies quite extensively, both here and in his conclusion. This great divide plays its familiar role of straw man, to be quickly knocked down. However the author also expresses his intrigue about the "inherent inertia of culture» (p. 28); suggesting that the deference to their ancestors shown by Yukuna and other Arawakan-speakers in Amazonia, might account for the shared structural characteristics between these groups as they have been documented by Santos-Granero and Hill (2002).

3 In Chapter 2 the torrid historical story of the Yukuna, who have gone through the era of slave raids, rubber boom and missionary schooling, is well evoked by Schackt. He reproduces Yukuna family history, as it was recounted to him, in portions of italicised text and supplements it with details gleaned from missionary and historical sources. Throughout the book, Yukuna are cited at length, either when they give autoanthropological explanations e.g. of maloca dances (p. 89) or as an expedient means to present specific versions of creation myth. The latter is the case in Chapter 6, where the majority of the text reproduces raw Yukuna myth narratives. I find it problematic - in a work which clearly claims to illuminate Yukuna orientation to knowledge and not merely to present their heritage for folkloric purposes - that unnamed Yukuna should be left to speak for themselves.

4 Nonetheless, at the heart of the book is Yukuna oral tradition, presented in Chapters 5, 6, and 7. Chapter 5 presents the story of the Kamijeya sib's apical ancestor, Periyo, to whom all true Yukuna look for lessons about how to lead a model maloca community. Just as Periyo's younger brother split from Periyo to form his own maloca only with Periyo's guidance and consent, so today aspiring maloca-owners need the permission of an established maloca owner to do so (p.98). In this way, down the generations, malocas have proliferated by successive off-shoot, but Yukuna have remained Yukuna by ensuring that prospective maloca leaders are equipped to transmit ancestral knowledge. Today, Yukuna fear that everyone aspires to maloca ownership; there are too many malocas, resting on too little thought for the ancestors. The brief reference to the actual dynamics of new maloca creation provided in Chapter 4 is fascinating. We learn that in 1984-1985, most Yukuna no longer dwelt in the malocas themselves but rather in nuclear family platform houses located in the surroundings. When a son builds his nuclear family home " as a single-post mini-maloca, it may be taken as a sign that he aspires one day to become the owner of a true full-sized maloca. Each time the roof of the mini-maloca needs to be rethatched, the owner may expand its size as well or, one day, build a bigger four-post maloca beside it» (p. 76). Given that the book returns, again and again, to the 
trope of the maloca, which is something like the root of Yukuna social and cosmological imagination, it is a pity that so little attention is paid by Schackt to how Yukuna actually live in and use their dwellings and their ceremonial maloca. In general, it is a pity the author gives less space to details about social process than he does to ideal typical descriptions.

Because Periyo is at the root of Yukuna historical time, which the author reckons to go back some 10-12 generations, stories of Periyo are defined as semi-historical legends (p. 115). Nonetheless they are also myths, in the Malinowskian sense of being charters for moral life. Chapter 6 turns to the Yukuna epic myth cycle in which universal ancestors, who have no known genealogical links with contemporary people, bring about the first maloca, the river basin, the staple crops, and heavenly bodies. As I mentioned above, in this chapter Yukuna narratives are left to speak to themselves.

Chapter 7 concerns Yukuna cosmos and conception of death and includes an intriguing but barebones description of a genre of maloca dance known as Baile de los Muñecos in which animal spirit guests are invited, species after species, to dance and drink in the malocas. The author tells us that the most elaborate of these dances includes the impersonation of more than 70 different species, represented by subtly different masks (p. 152). However, again, the commentary provided is disappointingly superficial: we learn that the dance is concerned with the relationship between layers of the cosmos and between men and animals. The author swiftly turns to the presentation of another myth, one in which animals host their own maloca dances. The connection between this myth and the dances is implied rather than explored.

7 The chapter on Yukuna shamanism (Chapter 8), more reflective and analytical, is fascinating. Yukuna compare their own shamanic tradition explicitly with that of the Makuna and other neighbours, whose shamanism depends on hallucinogenic yage; Yukuna say their own shamanism relies on their ancestors'pensamiento (p. 161). Since all Yukuna men have gained some part of this ancestral power through Yurupary initiation, they are all shamans to some degree. Schackt succinctly states that "Yukuna appear to consider the Yurupary rituals as a kind of basic course in shamanism» (p. 172). These " courses" take place regularly throughout men's lives, strengthening their bodies and shamanic proficiency through contact with ancestral knowledge.

Despite the book's thematic heart being relatively tightly defined, Schackt covers a lot of extra ground. This may be because when he conducted his fieldwork in 1985, only a few brief ethnographic sketches of the Yukuna existed in print (p. 68, footnote 27). Since then, a significant corpus has developed, including publications by one of Schackt's former informants, Carlos Matapí. Given this growing corpus, I wonder why the author felt compelled to cover everything from the rubber boom and missionaries, through the origin of the river basin and heavenly bodies, to maloca architecture and masked dances? Schackt even covers Yukuna Yurupary rites briefly (pp. 169-172), though he admits never having observed them first hand. This tendency to " cover all the bases " will make the book useful for comparative purposes, particularly to scholars interested in the North-West Amazonian region. For others the book will be hard work due to the rather roving character of the narrative, which presents a lot of information without a clear sense of how it illuminates central themes. There are also oddities to the book's structure, which make it more of a challenge than it should be for the reader. For example, we have to wait until the beginning of Chapter 6 for a clear, pragmatic statement of what a maloca is - «a local cooperative group settled in or around a 
riverside maloca surrounded by gardens " (p. 96). In a similar vein, only in Chapter 9 do we learn what a Yukuna patri-sib actually looks like, though patri-sibs are the key unit to which knowledge and malocas are ascribed throughout the book.

The book ends disappointingly with a return to the discussion of myth and history with which it began, again launching off from a caricature of Lévi-Strauss's distinction between hot and cold societies, which is put alongside Goody's (1977) tired distinction between oral and literate traditions (which has been thoroughly deconstructed in recent work on Amerindian epistemology e.g. Déléage 2010, 2013; Hugh-Jones 2010; Salomon 2004; Salomon and Niño-Murcia 2011). The Yukuna are not " deeply "cold" » (p. 208) because their oral tradition marries a corpus of epic creation myth with life stories of recent lineal ancestors. Although these two genres seem so clearly to divide at the point where family history ends ( 12 generations back) and a remote " mythical» era begins, the Yukuna do not make this distinction: «from the Yukuna point of view, my concern about a logically consistent chronology is simply not relevant " (p. 210). It is a shame that this is where the book ends, for this would seem to be the starting point for a deeper exploration of Yukuna epistemology and notions of temporality. Instead, the book is oriented around debates about Amerindian orientations to myth and history that feel stale to readers who have already read works by Gow (2001) or Heckenberger and Fausto (2007). This book is nonetheless a welcome addition to the growing body of literature on North-West Amazonian peoples; it is a bold illustration of the centrality of the maloca not only to the peoples' cosmologies and notions of personhood, but also to their reckonings of history.

\section{BIBLIOGRAPHY}

BLOCH Maurice

1977 « The past and the present in the present », Man, 12 (2), pp. 278-291.

DÉLÉAGE Pierre

2010 « Rituels du livre en Amazonie », Cahiers des Amériques latines, 63-64, pp. 229-250.

2013 Inventer l'écriture, Les Belles Lettres, Paris.

GOODY Jack

1977 The domestication of the savage mind, Cambridge University Press, Cambridge.

Gow Peter

2001 An Amazonian myth and its history, Oxford University Press, Oxford.

HECKENBERGER Michael and Carlos FAUSTO (eds)

2007 Time and memory in indigenous Amazonia: anthropological perspectives, University Press of

Florida, Gainesville.

HUGH-JONES Stephen

2010 « Entre l'image et l'écrit. La politique tukano de patrimonialisation en Amazonie », Cahiers

des Amériques latines, 63-64, pp. 195-227.

Journal de la Société des américanistes, 100-2 | 2014 
SALOMON Franck

2004 The cord keepers: khipus and cultural life in a Peruvian village, Duke University Press, Durham.

SALOMON Franck and Mercedes NIÑO-MURCIA

2011 The lettered mountain: a Peruvian village's way with writing, Duke University Press, Durham.

SANTOS-GRANERo Fernando and Jonathan David HILL (eds)

2002 Comparative Arawakan histories: rethinking language family and culture area in Amazonia, University of Illinois Press, Urbana.

\section{AUTHOR}

\section{CHLOÉ NAHUM-CLAUDEL}

Research fellow, Pembroke College, University of Cambridge 